\title{
ANALISIS HASIL BELAJAR FISIKA KELAS XI MIPA SMA NEGERI 2 POLEWALI
}

\author{
Arham* \\ Universitas Negeri Makassar \\ arhambasyar@gmail.com \\ Salamang Salmiah Sari \\ Universitas Negeri Makassar \\ salmiahsari@unm.ac.id \\ Nama Penulis 4 \\ Universitas Negeri Makassar \\ penulis@unm.ac.id \\ Nama Penulis 4 \\ Universitas Negeri Makassar \\ penulis@unm.ac.id \\ *koresponden author
}

\begin{abstract}
Abstrak - Penelitian ini menggunakan metode deskriptif dengan pendekatan kuantitatif yang bertujuan untuk menganalisis informasi tentang gambaran hasil belajar fisika di SMA Negeri 2 Polewali tahun ajaran 2019/2020. Subjek dalam penelitian ini adalah peserta didik kelas XI MIPA SMA Negeri 2 Polewali yang berjumlah 103 orang. Tujuan penelitian ini untuk memperoleh data kemampuan kognitif peserta didik dengan memberikan tes tertulis berupa pilihan ganda diakhir pembelajaran dan untuk memperoleh data kemampuan psikomotorik peserta didik dengan menggunakan lembar observasi serta ranah afektif menggunakan instrumen penilaian diri. Berdasarkan analisis statistik deskriptif diperoleh gambaran kemampuan kognitif peserta didik berada pada kategori tinggi dan gambaran kemampuan psikomotorik peserta didik berada pada kategori cukup terampil serta gambaran ranah afektif peserta didik berada pada kategori baik.
\end{abstract}

Kata Kunci: Kemampuan Kognitif, Kemampuan Psikomotorik, Ranah Afektif.

Abstract - This research used descriptive method with quantitative approach that aims to analyze information about the description of physics study result in SMA Negeri 2 Polewali with academic year 2019/2020. The subjects in this research is XI MIPA 2 students of SMA Negeri 2 Polewali, with 103 students. The purpose of this research is to obtain data cognitive abilities from students by giving a written test through the multiple choices form at end of learning and to obtain data psychomotor abilities from student using observation sheets and affective zone using self-assessment instruments. Based on descriptive statistical analysis obtained representation of cognitive abilities from student is high category and representation of psychomotor abilities from students is quite skilled category and description of affective aspect from students is good category.

Keywords: Cognitive Ability, Psychomotor Ability,Aspect of Affective. 


\section{A. PENDAhuluan}

Kurikulum 2013 menerapkan pembelajaran berbasis aktivitas, yang diharapkan akan menghasilkan insan Indonesia yang produktif, kreatif dan inovatif melalui penguatan sikap, pengetahun, dan keterampilan yang terintegrasi.

Menurut Arifin (2012:43) Penilaian adalah suatu proses atau kegiatan yang sistematis untuk mengumpulkan informasi tentang proses dan hasil belajar peserta didik dalam rangka membuat keputusan berdasarkan kriteria pertimbangan tertentu. Penilaian hasil belajar dibagi menjadi tiga ranah, yaitu ranah kognitif, afektif dan psikomotorik. Senada dengan hal tersebut Setiadi (2016:167) mengemukakan bahwa Pelaksanaan penilaian pada Kurikulum 2013 secara Eksplisit meminta agar guru-guru di sekolah seimbang dalam melakukan penilaian di tiga ranah domain, yaitu kognitif, afektif dan psikomotor sesuai dengan tujuannya yang hendak diukur.

Uno (2012:117), mengemukakan bahwa Penilaian hasil belajar secara esensial bertujuan untuk mengukur keberhasilan pembelajaran yang dilakukan oleh guru dan sekaligus mengukur keberhasilan peserta didik dalam penguasaan kompetensi. Dalam hal ini, guru dapat melakukan refleksi dan evaluasi terhadap kualitas pembelajaran yang telah dilakukan. Apakah metode, strategi, media, model pembelajaran dan hal lain yang dilakukan dalam proses belajar mengajar itu tepat dan efektif atau sebaliknya bisa dilihat dari hasil belajar yang diperoleh peserta didik.

Sistem penilaian dan kegiatan belajar mengajar merupakan kegiatan yang saling berkaitan. Hal tersebut senada dengan Purwanto (2002:8) yang mengemukakan bahwa "Tanpa adanya penilaian, tidak akan terjadi umpan balik. Tanpa umpan balik, tidak akan diperoleh pengetahuan yang baik tentang hasil. Tanpa pengetahuan tentang hasil, tidak dapat terjadi perbaikan yang sistematis dalam belajar".

Sehingga rumusan masalah pada penelitian ini adalah; (1) Bagaimana gambaran kemampuan kognitif peserta didik? (2) Bagaimana gambaran kemampuan psikomotorik? (3) Bagaimana gambaran ranah afektif peserta didik?

Iskandar (2013:7), menjelaskan bahwa penilaian adalah proses pengumpulan dan pengolahan informasi untuk mengukur pencapaian peserta didik. Selain itu, pendapat lain yang dikemukakan oleh Dimiyanti dan Mudjono (2006:3) bahwa hasil belajar merupakan hasil dari suatu interaksi tindak belajar dan tindak mengajar. Menurut Sudjana (2002:133), hasil belajar peserta didik pada hakikatnya adalah perubahan tingkah laku sebagai hasil belajar dalam pengertian yang lebih luas mencakup bidang kognitif, bidang afektif dan bidang psikomotorik, untuk lebih jelasnya sebagai berikut:

1. Kemampuan Kognitif

Menurut Yaumi (2013:169), Aspek kognitif adalah suatu ranah berfikir tentang fakta-fakta spesifik, pola prosedural, dan konsep-konsep dalam mengembangkan pengetahuan dan keterampilan intelektual. Sedangkan menurut Hardianti (2018:557) Kognitif didefenisikan sebagai proses mental atau aktivitas pikiran.

Sedangkan menurut Ali dan Khaeruddin (2012:6), Ranah kognitif adalah mengenai kemampuan intelektual peserta didik seperti yang ditampakkan dalam menyelesaikan soal-soal fisika,

Pada tahun 2013, Ayub mengemukakan wujud dari kemampuan kognitif menurut taksonomi Anderson dan Krathwohl terdiri atas enam tingkatan, yaitu; mengingat, memahami, menerapkan, menganalisis, mengevaluasi, mencipta.

2. Kemampuan Psikomotorik 
Penilaiain psikomotorik adalah penilaian untuk mengukur pencapaian kompetensi peserta didik terhadap kompetensi dasar pada KI-4. (kemendikbud, 2015:22). Menurut Octavia (2017:114), ranah psikomotorik merupakan ranah yang berkaitan dengan keterampilan atau kemampuan bertindak setelah seseorang menerima pengalaman belajar tertentu. Sedangkan Menurut Firman, 1995 dalam (Sugiarti, 2018:78) kemampuan psikomotorik dapat dikembangkan melalui praktikum.

\section{Ranah Afektif}

Menurut Mukrohmi (2013:7) Ranah afektif adalah ranah yang berkaitan dengan sikap dan nilai. Sedangkan menurut Atina (2016:13) Kemampuan afektif merupakan bagian dari hasil belajar yang memiliki peran yang sangat penting. Kompetensi sikap yang dimaksud adalah ekspresi nilai-nilai atau pandangan hidup yang dimiliki oleh seseorang dan diwujudkan dalam perilaku (kemendikbud, 2017:1).

Ranah afektif adalah segala sesuatu yang berkaitan dengan aspek sikap, minat, dan nilai (krathwohl, 1974). Pada umumnya, kegiatan pengumpulan data dilakukan secara non-ujian/ survey (Susetyo, 2015:52).

Kurikulum 2013 membagi kompetensi sikap menjadi dua, yaitu sikap spritual yang terkait dengan pembentukan peserta didik yang beriman dan bertakwa, dan sikap sosial yang berkaitan dengan pembentukan karakter peserta didik yang berahlak mulia, jujur, disiplin, bertanggung jawab, toleransi, gotong royong, santun, dan percaya diri.

\section{B. METODE}

Jenis penelitian ini adalah penelitian deskriptif. Subjek penelitian ini adalah peserta didik kelas XI MIPA SMA Negeri 2 Polewali tahun ajaran 2019/2020 dengan jumlah peserta didik sebanyak 103 orang.

Gambaran kemampuan kognitif peserta didik diperoleh dari skor kemampuan kognitif dalam menjawab tes pilihan ganda pada materi kesetimbangan benda tegar, elastisitas, pegas dengan indikator menerapkan dan menganalisis sesuai Kompetensi Dasar pada materi.

Gambaran kemampuan psikomotorik peserta didik diperoleh dari skor kemampuan psikomotorik dalam melakukan praktikum pada percobaan kesetimbangan benda tegar, pegas, dan archimedes. Skor tersebut diperoleh dari pengamatan yang dilakukan oleh observer dengan indikator yang digunakan dalam instrumen adalah mempersiapkan, merangkai, dan mengolah data dan menyimpulkan.

Gambaran ranah afektif peserta didik diperoleh dari skor kemampuan afektif dalam menjawab instrumen penilaian diri dengan aspek spritual dan aspek sosial.

Teknik pengambilan data untuk kemampuan kognitif menggunakan instrumen tes berupa pilihan ganda. Tiap soal yang dijawab benar diberi skor 1 sedangkan untuk soal yang dijawab salah diberi skor 0 . Pengumpulan data kemampuan kognitif dilakukan pada saat materi peserta didik telah mempelajari materi kesetimbangan benda tegar, elastisitas, dan fluida statis.

Untuk kemampuan psikomotorik menggunakan instrumen penilaian kinerja pada saat peserta didik melaksanakan kegiatan peraktikum di laboratorium. Instrumen penilaian kinerja yang digunakan adalah penilaian (rating scale). Terdapat 4 aspek psikomorik yang dikembangkan, dengan total 8 indikator, tiap 1 indikator yang muncul memiliki rentang poin $0-3$ sehingga skor tertinggi yang mungkin dicapai adalah 24 poin, dan skor terendah adalah 0 .

Untuk ranah afektif Instrumen yang digunakan berupa penilaian diri dengan menggunakan (skala likert). Jumlah butir pernyataan sebanyak 30 butir. Tiap butir pernyataan akan memliki rentang poin 1 
- 4 dengan kriteria secara berturut-turut adalah "tidak pernah", "kadang-kadang", "sering", dan "selalu".

\section{HASIL DAN PEMBAHASAN}

1. Kemampuan Kognitif

Statistik skor kemampuan kognitif peserta didik kelas XI di SMA Negri 2 Polewali dihasilkan dari tes kemampuan kognitif peserta didik pada materi kesetimbangan benda tegar, elastisitas, dan fluida statik. dengan jumlah subjek percobaan adalah 103 peserta didik. Dari analisis data tersebut diketahui skor ideal maksimum adalah 28, skor ideal minimum adalah 0 , skor tertinggi sebesar 27, skor terendah sebesar 5, varians sebesar 33,53, standar deviasi adalah 5,79, dan skor rata-rata 16,52.

Gambaran persentase skor kemampuan kognitif peserta didik pada penelitian ini dapat dilihat pada Gambar 1.

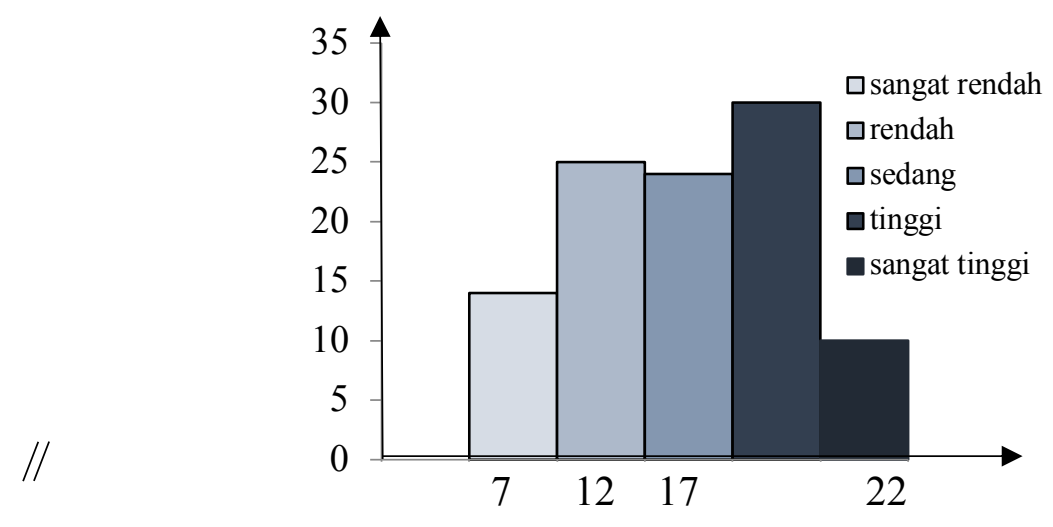

Gambar 1. Histogram Skor Kemampuan Kognitif peserta didik

Data kemampuan kognitif peserta didik dalam penelitian ini diperoleh dari data skor tes kemampuan kognitif peserta didik yang diberikan di akhir pembelajaran berupa tes pilihan ganda sebanyak 28 butir soal. Hasil analisis yang diperoleh dari subjek percobaan dengan standar deviasi sebesar 5,79. Selanjutnya data yang diperoleh diklasifikasikan menurut pengkategorian kemampuan kognitif sehingga dihasilkan 13,59\% peserta didik pada kategori sangat rendah, 24,27\% peserta didik berada pada kategori rendah, 23,30\% peserta didik pada kategori sedang, 29,13\% peserta didik pada kategori tinggi, dan 9,71\% peserta didik pada kategori sangat tinggi. Sehingga didapatkan skor rata-rata tes kemampuan kognitif sebesar 16,52 atau berada pada kategori tinggi.

2. Kemampuan Psikomotorik

Statsitik skor kemampuan psikomotorik peserta ddik pada saat melakukan praktikum dengan percobaan kesetimbangan benda tegar, pegas, dan archimedes, diketahui bahwa jumlah subjek percobaan adalah sebanyak 103 peserta didik. Dari jumlah subjek coba tersebut dihasilkan skor ideal maksimum sebesar 24, skor ideal minimum adalah 0 , skor tertinggi yang diperoleh peserta didik pada saat percobaan sebesar 23, skor terendah yang diperoleh peserta didik pada saat percobaan adalah 4 , sehingga diperoleh varians sebesar 22,52, standar deviasi sebesar 4,75, dan skor rata-rata kemampuan psikomotorik peserta didik yang diperoleh adalah 12,05.

Gambaran persentase skor kemampuan psikomotorik peserta didik dalam melaksanakan praktikum pada penelitian ini dapat dilihat pada Gambar 2. 


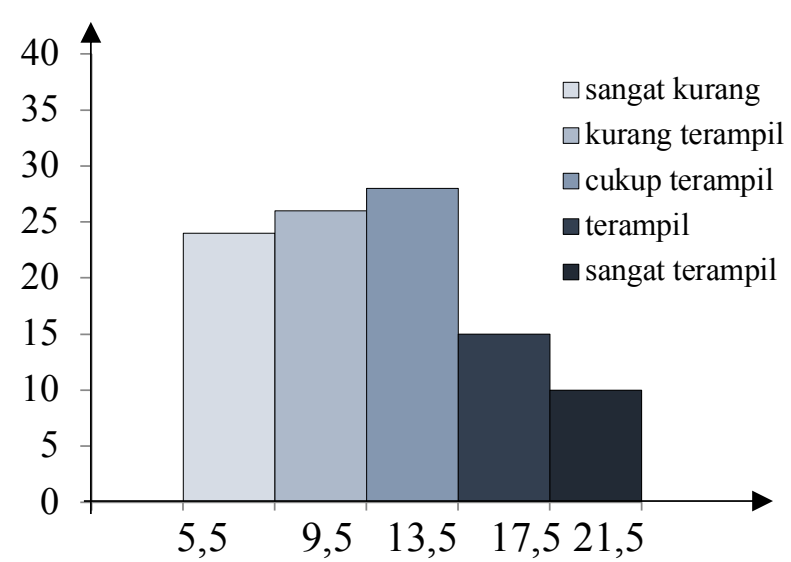

Gambar 2. Histogram Skor Kemampuan Psikomotorik peserta didik

kemampuan psikomotorik peserta didik dalam melakukan praktikum dengan subjek coba, diperoleh hasil analisis kemampuan psikomotorik dengan standar deviasi sebesar 4,75. Hasil data tersebut diklasifikasikan berdasarkan pengaktegorian kemampuan psikomotorik dan terdapat 23,30\% peserta didik berada pada kategori sangat kurang terampil, 25,24\% peserta didik berada pada kategori kurang terampil, 27,19\% peserta didik pada kategori cukup terampil, 14,56\% peserta didik berada pada kategori terampil, 9,71\% peserta didik berada pada kategori sangat terampil. Dari seluruh data tersebut dapat diperoleh skor rata-rata kemampuan psikomotorik diperoleh sebesar 12,05 atau berada pada kategori cukup terampil.

3. Ranah afektif

Statistik skor ranah afektif diperoleh bahwa jumlah subjek percobaan adalah sebanyak 103 peserta didik. Dari jumlah subjek coba tersebut dihasilkan skor ideal maksimum sebesar 120, skor ideal minimum adalah 30, skor tertinggi yang diperoleh peserta didik pada saat percobaan sebesar 107, skor terendah yang diperoleh peserta didik pada saat percobaan adalah 38 , sehingga diperoleh varians sebesar 298,64, standar deviasi sebesar 17,28 dan skor rata-rata ranah afektif peserta didik adalah 88,97.

Gambaran persentase skor pada ranah afektif peserta didik dalam penelitian ini dapat dilihat pada Gambar 3.

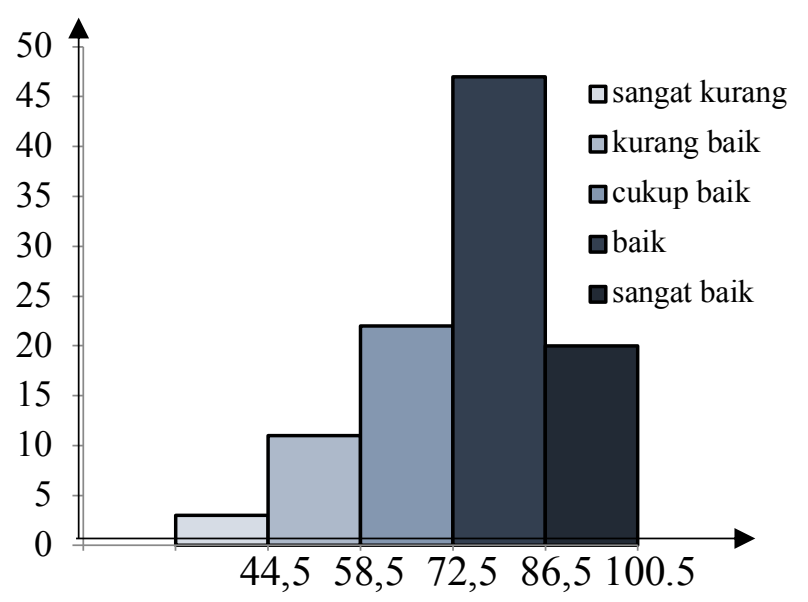

Gambar 3. Histogram Skor Ranah Afektif peserta didik

Berdasarkan hasil analisis kemampuan ranah afektif diperoleh standar deviasi sebesar 17,28. Selanjutnya data yang diperoleh tersebut diklasifikasikan berdasarkan pengkategorian kemampuan 
ranah afektif sehingga dihasilkan 19,42\% peserta didik pada kategori sangat baik, 45,63\% peserta didik berada pada kategori baik, 21,36\% peserta didik pada kategori cukup baik, 10,68\% peserta didik pada kategori kurang baik, dan 2,91\% peserta didik pada kategori sangat kurang baik. Dari keseluruhan data tersebut dapat diketahui bahwa ranah afektif peserta didik berada pada kategori baik dengan persentase $83,15 \%$. Dari keselurahan data tersebut diperoleh skor rata-rata dari kemampuan ranah afektif sebesar 88,97 atau beradaa pada kategori baik.

\section{SIMPULAN}

Berdasarkan hasil penelitian dan pembahasan dapat disimpulkan sebagai berikut. (1) Gambaran kemampuan kognitif peserta didik pada kelas XI MIPA SMA Negeri 2 Polewali berada pada kategori tinggi. (2) Gambaran kemampuan psikomotorik peserta didik berada pada kategori cukup terampil. (3) Gambaran ranah afektif peserta didik berada pada kategori baik.

\section{DAFTAR RUJUKAN}

Ali, S dan Khaeruddin. (2012). Evaluasi Pembelajaran. Makassar: Badan Penerbit Universitas Negeri Makassar.

Arifin, Zainal. (2012). Evaluasi Pembelajaran. Bandung: PT. Remaja Rosdakarya.

Atina, Astri. (2016). Pengembangan Instrumen Penilaian Afektif (Attitude Toward Chemistry) dengan Teknik Peer dan Self Assessment Siswa SMA Negeri 2 Salatiga. Skripsi. Semarang: Universitas Negeri Semarang.

Ayub, Putu dan Edy Sujoko. (2013). Revisi Taksonomi Pembelajaran Benyamin S. Bloom. Satya Widya. Vol. 29 No. 1: hal 98.

Dimiyanti dan Mudjono, D. (2006). Belajar dan Pembelajaran. Jakarta: Rineka Cipta.

Hardianti, Tuti. (2018). Analisis Kemampuan Peserta Didik pada Ranah Kognitif dalam Pembelajaran FisikaSekolah Menengah Atas. Seminar Nasional Quantum \#25: hal 557.

Iskandar, H. (2013). Model Pengembangan Penilaian Hasil Belajar. Jakarta: Kementerian Pendidikan dan Kebudayaan Direktorat Jenderal Pendidikan Menengah Direktorat Pembinaan SMA.

Kemendikbud. (2015). Panduan Penilaian untuk Sekolah Menengah Atas. Jakarta: Direktorat Jenderal Pendidikan Dasar dan Menengah.

Kemendikbud. (2017). Panduan Penilaian Kompetensi Sikap Kurikulum 2013. Jakarta: Direktorat Jenderal Pendidikan Dasar Menengah.

Matondang, Zulkifli. (2009). Validitas dan Reliabilitas suatu Instrumen Penelitian. Jurnal Tabularasa PPS Unimed. Vol. 6. No.1: hal 93.

Muhammad, F. \& Djaali. (2003). Metodologi Penelitian Sosial (Bunga Rampai). Jakarta: PTIK Pres Jakarta \& CV. Restu Agung. 
Octavia, Friska. (2017). Eksplorasi Kemampuan Psikomotorik Siswa terhadap Kemampuan Memprediksi dan Mengobservasi ditinjau dari Gender. JPF Jurnal Pendidikan Fisika. Vol. 5. No. 2: hal 114.

Purwanto, M. Ngalim. (2002). Prinsip-prinsip dan Teknik Evaluasi Pengajaran, Bandung: PT Remaja Rosdakarya.

Purwanto. (2011). Evaluasi Hasil Belajar. Yogyakarta: Pustaka Pelajar.

Roestiyah. (2008). Strategi Belajar Mengajar. Jakarta: Rineka Cipta.

Setiadi, H. (2016). Pelaksanaan Penilaian pada Kurikulum 2013. Jurnal Penelitian dan Evaluasi Pendidikan. Vol. 20. No. 2: hal 167.

Sudjana, N. (2002). Penilaian Hasil Proses Belajar Mengajar. Bandung: PT. Remaja Rosda Karya.

Sudjana. (2005). Metode Statistika. Bandung: Tarsito.

Sugiarti. (2018). Penilaian Psikomotorik Peserta Didik Pembelajaran Fisika melalui Model Pembelajaran Guyded Inkuiri. Journal of Physic and Science Learning. Vol. 02. No. 1: hal 78.

Sugiyono. (2014). Metode Penelitian Kuantitatif, Kualitatif dan $R \& D$. Bandung: Alfabeta.

Susetyo, Budi. (2015). Prosedur Penyusunan dan Analisis Tes untuk Penilaian Hasil Belajar Bidang Kognitif. Bandung: Refika Aditama.

Uno, Hamsa B. (2012). Assessment Pembelajaran. Jakarta : PT. Bumi Aksara

Yaumi, M. (2013). Prinsip-Prinsip Desain Pembelajaran. Jakarta: Kencana. 